ФАКТОРИ ЗДОРОВОГО СПОСОБУ ЖИТТЯ СТУДЕНТІВ ЗАКЛАДІВ ВИЩОЇ ОСВІТИ Й ОСНОВНІ ФОРМИ ПРОВЕДЕННЯ НИМИ ВІЛЬНОГО ЧАСУ

\title{
FACTORS OF A HEALTHY LIFESTYLE FOR THE HIGH SCHOOL STUDENTS AND THE MAIN FORMS OF THEIR LEISURE
}

У статті висвітлюються переваги в дозвіллі хлопців і дівчат різних курсів педагогічних спеціальностей ЗВО. Важливого значення тут набуває те, що стан здоров'я людини є визначальним у реалізаuіï себе, а стан здоров'я різних вікових груп населення у країні є показником потенціалу держави, їі спроможності існувати в майбутньому.

У зв'язку зі збільшенням кількості студентів у спеціальній медичній групі було проаналізовано тенденцію погіршення стану здоров'я тих осіб, які після медичного огляду були звільнені від занять. Здійснено аналіз літератури, в якій висвітлено, що студенти мають низький рівень фрізичної підготовленості, низьку мотивацію, не виявляють інтересу до змісту занять, у них не сфрормоване ціннісне ставлення до самостійних занять фрізичною культурою. Аналіз вільного часу студентів підтверджує слабку мотивацію до занять фрізичними вправами і спортом.

Здорового способу життя дотримуються не всі студенти. У деяких із них мають місце нездорові фрактори поведінки. Рівень фрізичного здоров'я студентів з 2-го по 4-й курс знижується і знаходиться у «небезпечній зоні» здоров'я, тобто у групі ризику з розвитку хронічних соматичних захворювань, пов'язаних із ендогенними фракторами.

Ієрархія видів захоплень на дозвіллі студентів педагогічних спеціальностей нефрізкультурного профрілю дівчат і хлопців схожа: найголовнішим захопленням (1 ранг) проведення вільного часу за такою фрормою, як «спілкування з друзями». Лише хлопиі 4-го курсу, єдині з усієї вибірки, на перше місце ставлять «заняття спортом». Друге рангове місце у студентів усіх курсів обох статей, крім четвертокурсників, за таким захопленням, як «прослуховування музики». Заняття руховою $і$ спортивною діяльністю серед студентів 2-3-го курсу отримала малозначимі рангові місця, поступаючись пасивним формам.
Ключові слова: здоров'я, студенти, фрізична культура, здоровий спосіб життя рухова активність.

The article highlights the advantages of leisure for male and female high school students of different years of study majoring in pedagogy. The state of human health is of great importance as it is decisive in the self-realization, and the state of health of different age groups of population in the country is the indicator of the state potential, its ability to exist in the future.

Due to the increase in the number of students in the special medical group, the tendency of health deterioration of those who were excused from attending the classes after medical examination was analyzed. The analysis of literature, which shows that students have low level of physical fitness, low motivation, do not show interest in the content of the classes, is carried out. It was also established that the students have an unformed values-based attitude to independent physical education. The analysis of students' leisure confirms the weak motivation to exercise and sports. Not all students keep a healthy lifestyle. Some of them have unhealthy behavioral factors. The level of physical health of students from the 2nd to the 4th year of study is decreasing and is in the "danger zone" of health, that is, they are at risk group for the development of chronic somatic diseases, connected with the endogenous factors. The hierarchy of types of hobbies of students majoring in pedagogy of non-cultural profile in their free time is similar by girls and boys: the most important kind of spending their free time (1st rank) is the form of "communication with friends". Only the boys of the 4th year of study, the only ones in the whole sampling, put "sports" in the first place. "Listening to music" took the second ranked place among the students of both sexes, of all the years of study, except the fourthyear students. Physical activities and sports activities $r$ got insignificant rank places among the students of the $2 d$ and $3 r d$ year of study, compared to the passive forms.

Key words: health, students, physical training, healthy lifestyle, physical activity.
Уманського державного педагогічного університету імені Павла Тичини
Постановка проблеми у загальному вигляді. Недотримання мінімумів рухової активності відображається на стані здоров'я студентів, який за об'єктивними медичними показниками є незадовільним. Студент ЗВО не має мотивації до занять фізичними вправами, адже на обов'язкових заняттях фрізичним вихованням на 1-2-му курсах він мало отримує практичних навичок до самостійної організації й управління своїм фрізичним станом. Самовдосконалення вимагає саморегуляції активної поведінки, щоб майбутній педагог вмів дозувати і контролювати своє активне життя, не завдаючи собі шкоди. Педагог фрізичного виховання має вміти впливати на мотивацію, сприяти самовдосконаленню студента, виробляти вміння саморе- гуляції активної поведінки. Здатність студентів до самоконтролю у процесі занять фрізичними вправами мотивує їх до самостійного та повноцінного активного і здорового життя.

Аналіз останніх досліджень і публікацій. Особливу цінність для студентів становить здоров'я. Геронтологи стверджують, що, якщо змолоду закласти гарну основу здоров'я, то тривале життя людини буде активним, а старість - без хвороб. Фахівці відзначають тісний взаємозв'язок здоров'я і навчання: чим міцніше здоров'я студентів, тим продуктивніше навчання [10]. Зарубіжні дослідження показують, що набута замолоду звичка нездорового способу життя може визначати стан здоров'я у зрілому віці [13]. 
Найгірше те, що проблеми зі станом здоров'я молоді, зокрема студентства, ніяк не покращуються, а навпаки, лише ускладнюються. Так, статистичні дані цільової комплексної програми «Фізичне виховання -здоров'я нації» інфрормують проте, що 90\% дітей, учнів і студентів мають відхилення у стані здоров'я, понад 50\% - незадовільну фрізичну підготовку, 61\% молоді віком 16-19 років мають низький і нижче середнього рівні фрізичного здоров'я, а віком 20-29 років - 67,2\% [12].

На думку В.М. Платонова, вища школа одержує 70\% хворих, а випускає - 90\% [8].

Такі вчені, як О. Романчишин, О. Сидорко, П. Мартин не виявляють суттєвих відмінностей між захворюваністю студентів різних вищих навчальних закладів. Студентів, які серйозно (з офрормленням листка непрацездатності) хворіли - 41,25\%: приблизно у два рази більше, ніж тих, які протягом року не хворіли жодного разу (26,99\%) в усіх педагогічних коледжах [11].

Досліджуючи динаміку стану здоров'я студентів гуманітарних вищих закладів освіти, A.І. Драчук констатує, що в останні роки виявлено велику кількість студентів із відхиленнями у стані здоров'я. Неухильно зростає кількість спеціальних медичних груп: якщо у 1996 р. студенти, котрі за станом здоров'я були віднесені до спеціальної медичної групи, склали 7,8\%, то на кінець їх четвертого курсу їх стало вже 16,2\%. Вивчення характеру захворювань показало, що найпоширенішими $€$ гострі респіраторні захворювання, якими студенти хворіють протягом навчання у ЗВО [3].

За статистичними даними медичного обстеження (2005-2011 рр.) О.І. Мозговий, І.С. Донченко встановили, що в Запорізькому національному університеті спостерігається тенденція до погіршення стану здоров'я студентів, тому що збільшується їх кількість у спеціальній медичній групі, та тих студентів, які після медичного огляду були звільнені від занять. У відсотках розподіл студентів до спеціальної медичної групи у 2005 р. склав 7,7\% студентів, у 2008 р. - 21,8\%, у 2009 р. 20,8\%, у 2010 р. -23\% та у 2011 р. - 20\%. Найбільший відсоток студентів, які входили до складу спеціальної медичної групи, спостерігався також у 2005 р., так само і по підготовчій медичній [7].

Дослідивши соматичне здоров'я студентів, Л.П. Долженко отримала результати, за якими юнаків із безпечним рівнем здоров'я всього 7\%, а дівчат - лише 3,5\%. За межею безпечного рівня здоров'я залишається 93,1\% юнаків і 96,5\% дівчат. Причину погіршення стану здоров'я молоді науковець вбачає в різних фракторах, зокрема в недостатній руховій активності, несвоєчасному харчуванні, великих розумових навантаженнях і стресах, недосипанні, наявності різних шкідливих звичок та ін., наслідках аварії на чАЕС [2].
Мета статті - дослідження процесу створення середовища, що сприяє фрізичному і моральному оздоровленню студентів, підтримці рівня здоров'я, його зміцненні, примноженню, фрормуванню навичок здорового способу життя, виховання культури здоров'я, що нейтралізує та знижує негативну дію зовнішніх і внутрішніх середовищних фракторів, підвищує їх стійкість до стресу.

Виклад основного матеріалу. Сьогодні стан здоров'я молодого покоління як майбутнього резерву й активу держави не є навіть задовільним. Так, за даними державної статистичної звітності про стан здоров'я дітей 0-17 років, у структурі захворюваності традиційно, як і в попередні роки, переважали хвороби органів дихання (66,78\%), шкіри та підшкірної клітковини (5,24\%), травми, отруєння та деякі інші наслідки дії зовнішніх чинників (3,65\%), деякі інорекційні та паразитарні хвороби (3,69\%), хвороби органів травлення $(3,65 \%)$, ока та його придаткового апарату (3,37\%). Сумарна частка цих хвороб становила 86,52\% [4].

Така ситуація зі станом здоров'я в будь-якому 3ВО. Не знайти жодної наукової статті, автори якої $б$ не нарікали на низький стан здоров'я студентської молоді. Навіть студенти низько оцінюють власне здоров'я.

Вивчаючи самооцінку рівня здоров'я студентами Луцького інституту розвитку людини Університету «Україна», Е. Косинський отримав дані, за якими респонденти розподілилися за чотирма варіантами відповідей (відмінний, добрий, задовільний, незадовільний) - 62,39\% опитаних оцінюють свій стан здоров'я як добрий, 18,35\% - відмінний, 17,43\% -задовільний і лише $1,83 \%$ - як незадовільний. За гендерним розподілом відмінним свій стан здоров'я вважають 10,6\% дівчат, а 65,2\% - добрим; 21,2\% - задовільним і лише 3,0\% - незадовільним. Серед юнаків своє здоров'я відмінним вважають 30,2\%, добрим $58,1 \%$, задовільним - 11,6\%, незадовільним стан здоров'я не назвав жоден юнак [5].

у подібному дослідженні серед юнаків В.Б. Базильчук установив, що самооцінка стану їх здоров'я дещо інша: 48,4\% вважають його задовільним, 37,3\% - добрим, 10,5\% - відмінним і 3,8\% - незадовільним [1].

Провівши анкетування за самооцінкою здоров'я студентів I і II курсів Національного аграрного університету, С. Присяжнюк, В. Краснов, Н. Федоріна встановили, що 30,4\% оцінюють власне здоров'я як добре, 58,6\% - задовільне, 10,6\% - погане і лише 0,4\% вважають своє здоров'я дуже поганим, зокрема: 23,3\% дівчат вважають своє здоров'я добрим, 64,7\% - задовільним і 12,0\% - поганим. Юнаки оцінили своє здоров'я так: 44,8\% вважають, що їх здоров'я добре, 46,6\% - задовільне, 7,8\% погане і 0,8\% - дуже погане. Суб'єктивна оцінка стану здоров'я дівчат і юнаків майже однакова [9]. 
У ЗВО здоров'ям студентів не переймається ніхто, а кількість академічних годин для занять фрізичною культурою у закладах нефрізкультурного профрілю, які хоча б частково знижували дефіцит рухової активності, всього 2 години на тиждень. Усе це не дозволяє зміцнювати здоров'я студентів і підвищувати їх рівень фрізичного стану. О.Т. Кузнєцова вказує ще на те, що ті умови й організація навчального процесу з фрізичного виховання, які практикують ЗВО, не тільки не сприяють поліпшенню здоров'я студентів, а й не підвищують розумової працездатності [6].

Такий стан здоров'я студентської молоді викликає неабияке занепокоєння і потребу працювати над фрормуванням мотивації до занять фрізичною культурою та підвищення рухової активності студентів.

Ми проводили дослідження в Уманському державному педагогічному університеті імені Павла Тичини, зі студентами педагогічних спеціальностей (історичний та природничо-географрічний фракультет) 2-4 курсів (30 хлопців і 30 дівчат на кожному із курсів).

Серед захоплень для проведення вільного часу респонденти обох статей надають однакові переваги. Найголовнішим захопленням (1 ранг) на дозвіллі хлопці (окрім четвертокурсників, які єдині з усієї вибірки на перше місце ставлять «заняття спортом») і дівчата називають «спілкування з друзями». Хлопці 4-го курсу спілкування з друзями поставили на 2-е місце. На друге місце студенти всіх курсів обох статей, окрім названих четвертокурсників, віднесли таке захоплення, як «прослуховування музики». 3 третього рангу спостерігаємо відмінності.

У хлопців пріоритетні захоплення в ієрархії переваг (особливо з 3-го рангу) проведення віль- ного часу (табл. 1.) залежать від курсу. Лише юнаки 2-го курсу визначають найважливіші види дозвілля (1-5 ранги) такі, як і їх одногрупниці та дівчата 3-4-го курсів. На 3-му місці у хлопців 2-го курсу «відвідування дискотек», 3-го - «читання художньої літератури», а в 4-го - «прослуховування музики». Види захоплення 3 4-го по 5-й ранг у хлопців ті самі, різниця лише в порядковому місці («читання художньої літератури» у хлопців 2-го і 4-го курсів на 4-му місці, «відвідування дискотек» у 3-4-го курсів на 5-му місці). «Допомога батькам» як пріоритет у виді дозвілля лише у хлопців 2-го курсу, тоді як для 3-4-го курсів ця діяльність малозначима (8-9 ранги). Заняття спортом є пріоритетним захопленням також для третьокурсників (4-й ранг) і малозначиме для 2-го курсу. Гра на музичних інструментах і співи на 6-му ранзі в 2-3-го курсів і на 12 місці в 4-го курсу. Малозначимими для хлопців 3-4-курсів є «гра у комп'ютерні ігри» (7-й і 6-й ранг) і «зустріч із дівчиною» (9-й і 7-й ранги), а другокурсники ці види захоплень взагалі відкидають (11-12 ранги).

На останніх (15 ранг) місцях в ієрархії дозвілля у хлопців 3-4-го курсів така діяльність, як «читання спеціальної літератури», а в 2-го курсу - «заняття технікою». Відкидають також хлопці такі захоплення, як «відвідування церкви» (13-14-й ранги в 2-3-го курсів та 10-й у 4-го курсу), «водіння автомобіля» (13-14-й ранги в 2-го і 4-го та 11-й у 3-го курсів), «малювання» (13-14-й ранги у хлопців 3-4-го курсів і 10-й ранг у хлопців-другокурсників).

У дівчат усіх курсів пріоритетні місця в ієрарxiї видів дозвілля (табл. 2.) однакові від 1-го до 5-го рангу (виняток становить 3-й ранг четвертокурсниць). На 2-му місці «прослуховування музики», 3-му - «відвідування дискотек» у дівчат 2-3-го курсів і «заняття спортом» на 4-му курсі;

Переваги в дозвіллі хлопців різних курсів педагогічних спеціальностей

Таблиця 1

\begin{tabular}{|c|c|c|c|c|c|c|}
\hline \multirow{3}{*}{ Захоплення } & \multicolumn{6}{|c|}{ Kурс } \\
\hline & \multicolumn{2}{|c|}{ другий } & \multicolumn{2}{|c|}{ третій } & \multicolumn{2}{|c|}{ четвертий } \\
\hline & сума балів & ранг & сума балів & ранг & сума балів & ранг \\
\hline спілкування з друзями & 58 & 1 & 78 & 1 & 83 & 2 \\
\hline читання художньої літератури & 186 & 4 & 161 & 3 & 184 & 4 \\
\hline гра на музичних інструментах, співи & 242 & 6 & 245 & 6 & 287 & 12 \\
\hline прослуховування музики & 64 & 2 & 99 & 2 & 132 & 3 \\
\hline відвідування дискотеки & 177 & 3 & 203 & 5 & 210 & 5 \\
\hline заняття спортом & 258 & 7 & 189 & 4 & 74 & 1 \\
\hline вивчення іноземної мови & 259 & 8 & 290 & 12 & 262 & 8 \\
\hline гра в комп'ютерні ігри & 294 & 11 & 251 & 7 & 222 & 6 \\
\hline малювання & 264 & 10 & 325 & 13 & 296 & $13-14$ \\
\hline заняття технікою & 346 & 15 & 276 & 10 & 278 & 11 \\
\hline водіння автомобіля & 338 & $13-14$ & 285 & 11 & 296 & $13-14$ \\
\hline допомога батькам & 212 & 5 & 258 & 8 & 270 & 9 \\
\hline відвідування церкви & 338 & $13-14$ & 328 & 14 & 271 & 10 \\
\hline зустріч із хлопцем / дівчиною & 302 & 12 & 274 & 9 & 229 & 7 \\
\hline читання спеціальної літератури & 262 & 9 & 338 & 15 & 339 & 15 \\
\hline
\end{tabular}


Переваги в дозвіллі дівчат різних курсів педагогічних спеціальностей

\begin{tabular}{|c|c|c|c|c|c|c|}
\hline \multirow{3}{*}{ Захоплення } & \multicolumn{6}{|c|}{ Kурс } \\
\hline & \multicolumn{2}{|c|}{ другий } & \multicolumn{2}{|c|}{ третій } & \multicolumn{2}{|c|}{ четвертий } \\
\hline & сума балів & ранг & сума балів & ранг & сума балів & ранг \\
\hline спілкування з друзями & 73 & 1 & 58 & 1 & 57 & 1 \\
\hline читання художньої літератури & 157 & 4 & 186 & 4 & 197 & 4 \\
\hline гра на музичних інструментах, співи & 247 & 8 & 242 & $8-7$ & 229 & 7 \\
\hline прослуховування музики & 128 & 2 & 64 & 2 & 117 & 2 \\
\hline відвідування дискотеки & 145 & 3 & 177 & 3 & 225 & 6 \\
\hline заняття спортом & 203 & 6 & 258 & 9 & 186 & 3 \\
\hline вивчення іноземної мови & 232 & 7 & 259 & 10 & 257 & 9 \\
\hline гра в комп'ютерні ігри & 278 & 11 & 294 & 11 & 249 & 8 \\
\hline малювання & 267 & 10 & 242 & $8-7$ & 271 & 11 \\
\hline заняття технікою & 358 & 15 & 346 & 15 & 329 & 13 \\
\hline водіння автомобіля & 351 & 13 & 338 & $14-13$ & 361 & 15 \\
\hline допомога батькам & 202 & 5 & 197 & 5 & 206 & 5 \\
\hline відвідування церкви & 354 & 14 & 338 & $14-13$ & 323 & 12 \\
\hline зустріч із хлопцем / дівчиною & 252 & 9 & 302 & 12 & 337 & 14 \\
\hline читання спеціальної літератури & 299 & 12 & 240 & 6 & 270 & 10 \\
\hline
\end{tabular}

4-е місце за «читанням художньої літератури» і 5-те - «допомога батькам».

Останні місця (відкинуті захоплення) займають подібні захоплення - «заняття технікою» (останнє 15 місце в дівчат 2-3-го курсів і 13-те - в 4-го курсу), «водіння автомобіля» (13-14-й ранги у 2-3-курсу і 15-й - в 4-го курсу), «відвідування церкви» (13-14-й ранги у 2-3-курсів і 12-й - в 4-го курсу). Для дівчат 3-го (12 ранг) і 4-го (14 ранг) курсів такий вид проведення вільного часу, як «зустріч із хлопцем» також $є$ відкинутим, хоча в дівчат 2-го курсу такий вид захоплення на 9 місці. Малозначимими в ієрархії видів дозвілля $€$ «малювання» (10-й ранг у 2-го курсу, 11-й ранг у 3-го курсу і 8-7-й - у 3-го), «гра в комп'ютерні ігри», «гра на музичних інструментах», «читання спеціальної літератури» та «вивчення іноземної мови».

Висновки. Отже, в ієрархії видів дозвілля тим формам, що пропонує університет, студенти відводять малозначимі місця. Ієрархія видів захоплень на дозвіллі студентів педагогічних спеціальностей несрізкультурного профрілю дівчат і хлопців схожа: найголовнішим захопленням (1 ранг) є проведення вільного часу за такою формою, як «спілкування з друзями». Лише хлопці 4-го курсу, єдині з усієї вибірки, на перше місце ставлять «заняття спортом». Друге рангове місце у студентів усіх курсів обох статей, окрім четвертокурсників, за таким захопленням, як «прослуховування музики». Заняття руховою і спортивною діяльністю серед студентів 2-3-го курсу отримала малозначимі рангові місця, поступаючись пасивним формам.

\section{БІБЛІОГРАФІЧНИЙ СПИСОК:}

1. Базильчук В.Б. Організаційні засади активізації спортивно-оздоровчої діяльності студентів в умовах вищого навчального закладу : автореср. дис. ... канд. наук з фріз. виховання і спорту. Львів, 2004. 20 с.

2. Долженко Л.П. Оздоровчий напрямок занять в фрізичному вихованні студентів. Педагогіка, психологія та медико-біологічні проблеми фрізичного виховання і спорту. 2003. № 19. С. 23-30.

3. Драчук А.І. Динаміка стану здоров'я студентів гуманітарних вищих закладів освіти. Педагогіка, психологія та медико-біологічні проблеми фрізичного виховання і спорту. 2002. № 22. С. 23-28.

4. Дудіна О.О. Захворюваність дитячого населення. Щорічна доповідь про стан здоров'я населення, санітарно-епідемічну ситуацію та результати діяльності системи охорони здоров'я України. 2014 рік. Київ : ДУ «Український інститут стратегічних досліджень МОЗ України», 2015. С. 52.

5. Косинський Е. Самооцінка стану здоров'я студентів і їх мотивація до занять фрізичним вихованням. Молода спортивна наука України : збірник наукових праць із галузі фріз. виховання, спорту і здоров'я людини. Львів, 2011. Вип. 15, т. 2. С. 106-109.

6. Кузнєцова О.Т. Фізична і розумова працездатність студентів з низьким рівнем фрізичної підготовленості : автореср. дис. ... канд. наук з фріз. виховання та спорту. Львів, 2005. 22 с.

7. Мозговий О.І., Донченко І.С. Загальна характеристика стану здоров'я студентів 3ВО. Вісник Запорізького національного університету. 2012. № 2 (8). C. 92-97.

8. Платонов В. Фізична культура - культура здоров'я. Фізичне виховання в школі. 2009. № 2. C. 40-43. 
9. Присяжнюк С.І., Краснов В.П., Федорина Н.Б. Проблема здоров'я та фрізичної підготовленості студентської молоді аграрних вищих навчальних закладів. Педагогіка, психологія та медико-біологічні проблем фрізичного виховання та спорту. 2003. № 17. С. 52-56.

10. Раевский Р.Т., Канишевский С.М. Здоровье, здоровый и оздоровительный образ жизни студентов / под общ. ред. Р.Т. Раевского. Одесса : Наука и техника, 2008. 556 с.

11. Романчишин О., Сидорко О., Мартин П. Спосіб життя, працездатність і захворюваність студентів педагогічних коледжів. Педагогіка, психологія та медико-біологічні проблеми фрізичного виховання і спорту. 2010. № 6. С. 93-97.

12. Цільова комплексна програма «Фізичне виховання - здоров'я нації» / затверджено Указом Президента України від 1 вересня 1998 р. № 963/98. URL: http://zakon2.rada.gov.ua/laws/show/963\% D0\%BO/98.

13. Addressing the socioeconomic determinants of healthy eating habits and physical activity levels among adolescents. URL: http://www.euro.who.int/document/ e89375.pdf. 